\title{
Korelasi antara Kadar Testosteron dan Proses Remodeling Ventrikel Kiri pada Penderita Infark Miokardium Akut
}

\author{
Mohammad Rizki Akbar, ${ }^{1}$ Tri Hanggono Achmad, ${ }^{2}$ Ieva B. Akbar, ${ }^{3}$ \\ Budhi Setianto Purwowiyoto ${ }^{4}$ \\ ${ }^{1}$ Departemen Kardiologi dan Kedokteran Vaskular Fakultas Kedokteran Universitas Padjadjaran Bandung \\ ${ }^{2}$ Departemen Biokimia dan Biologi Molekuler Fakultas Kedokteran Universitas Padjadjaran Bandung \\ 3Bagian Ilmu Faal Fakultas Kedokteran Universitas Islam Bandung \\ ${ }^{4}$ Departemen Kardiologi dan Kedokteran Vaskular Fakultas Kedokteran Universitas Indonesia Jakarta
}

\begin{abstract}
Abstrak
Infark miokardium akut merupakan penyebab utama kematian di dunia. Perbedaan jenis kelamin berperan terhadap mortalitas jangka panjang pascainfark miokardium yang menunjukkan gambaran pola fisiologi regenerasi miokardium yang spesifik. Kematian setelah infark miokardium lebih tinggi pada perempuan. Remodeling ventrikel kiri merupakan proses penyembuhan luka pascainfark miokardium yang menjadi petunjuk keadaan gagal jantung maupun kematian. Proses ini berpengaruh penting pada fungsi ventrikel dan prognosis survival yang dapat didiagnosis dengan pemeriksaan ekokardiografi. Terdapat kontroversi berkaitan dengan peranan androgen pada proses remodeling jantung. Walaupun masih terdapat perdebatan, androgen memiliki peran terhadap remodeling ventrikel kiri dan bersifat protektif terhadap proses fibrosis yang maladaptif. Dilakukan penelitian observasional analitik yang bersifat prospektif untuk mengkaji peranan testosteron terhadap remodeling ventrikel kiri pada pasien infark miokardium akut di RSUP Dr. Hasan Sadikin Bandung selama Maret-Oktober 2015. Penelitian dilakukan pada 6o orang laki-laki usia 40-77 tahun penderita infark miokardium akut. Pemeriksaan ekokardiografi, pengukuran kadar testosteron total, testosteron bebas, dan testosteron bioavailabel dilakukan sebanyak dua kali. Pemeriksaan pertama dilakukan saat pasien didiagnosis infark miokardium akut dan pengulangan 4-6 minggu kemudian. Usia rata-rata penderita 56,16 $\pm 8,48$ tahun. Bila dibanding dengan pemeriksaan pertama dan kedua, tampak peningkatan kadar testosteron total yang signifikan $(785,00 \pm 661,76 \mathrm{ng} / \mathrm{dL}$ vs $822,33 \pm 365,64$ $\mathrm{ng} / \mathrm{dL} ; \mathrm{p}=\mathrm{O}, 004)$, penurunan kadar testosteron bebas $(24,66 \pm 17,91 \mathrm{ng} / \mathrm{dL}$ vs $19,00 \pm 15,24 \mathrm{ng} / \mathrm{dL} ; \mathrm{p}=0,067)$, dan penurunan kadar testosteron bioavailabel $(475,21 \pm 353,10 \mathrm{ng} / \mathrm{dL}$ vs $394,98 \pm 314,85 \mathrm{ng} / \mathrm{dL} ; \mathrm{p}=0,166)$. Analisis korelasi Rank Spearman memperlihatkan korelasi bermakna antara testosteron bebas dan relative wall thickness $(\mathrm{p}=0,019)$, serta testosteron bioavailabel dengan relative wall thickness $(\mathrm{p}=0,014)$. Simpulan, testosteron berperan pada proses remodeling ventrikel kiri pascainfark miokardium akut yang diperlihatkan dengan peningkatan kadar testosteron total serta penurunan kadar testosteron bebas maupun testosteron bioavailabel yang memiliki afinitas yang kuat dengan kardiomiosit.
\end{abstract}

Kata kunci: Infark miokardium akut, remodeling ventrikel kiri, testosteron

\section{Corellation between Testosterone Level and Left Ventricular Remodeling Process in Acute Myocardial Infarction Patient}

\begin{abstract}
Myocardial infarction (MCI) is a leading cause of death worldwide. Gender differences in long term mortality after MCI lead to a specific physiologic pattern of myocardial regeneration. Moreover mortality after MCI was reported to be higher in women. Left ventricular remodeling is cardiac wound healing after MCI indicate a high risk of heart failure and death. This remodeling can importantly affect the function of the ventricle and prognosis for survival which can be diagnosed by echocardiography. Controversial information excert about the role of androgen in cardiac remodeling. Even the evidence still debatable, androgen has a role in left ventricular (LV) remodeling and protect heart from maladaptive fibrosis. A prospective analytical observational study was conducted to evaluate the role of testosterone in LV remodeling in acute myocardial infarction patients. The study comprised 60 men aged 40-77 years with acute myocardial infarction in Dr. Hasan Sadikin Hospital during March-October 2015. Echocardiographyc study and the level of total, free, and bioavailable testosterone were measured twice. The first measured when they diagnosed acute myocardial infarction and the second after 4-6 weeks. The age of patient was $56.16 \pm 8.487$ years old. Comparing the first and the second measure indicate that total testosterone significantly increased (785.00 $\pm 661.76 \mathrm{ng} / \mathrm{dL}$ vs $822.33 \pm 365.64 \mathrm{ng} / \mathrm{dL}, \mathrm{p}=0.004)$, free testosterone decreased $(24.66 \pm 17.91$ $\mathrm{ng} / \mathrm{dL}$ vs $19.00 \pm 15.24 \mathrm{ng} / \mathrm{dL}, \mathrm{p}=0.067)$, and bioavailable testosteron decreased $(475.21 \pm 353.10 \mathrm{ng} / \mathrm{dL} \mathrm{vs}$ $394.98 \pm 314.85 \mathrm{ng} / \mathrm{dL}, \mathrm{p}=0.166)$. Correlation analysis by Rank Spearman showed significantly correlation between free testosterone with relative wall thickness $(\mathrm{p}=0.019)$, and bioavailable testosterone with relative wall thickness $(\mathrm{p}=0.014)$. It is concluded that testosterone has a role on LV remodeling process after myocardial infarction showed by increasing of total testosterone and decreasing of free and bioavailable testosterone which have great affinity with cardiomyocyte.
\end{abstract}

Key words: Acute myocardial infarction, LV remodeling, testosterone

Korespondensi: E-mail:m_rizki_a@ymail.com 


\section{Pendahuluan}

Infark miokardium akut adalah merupakan salah satu manifestasi klinis penyakit arteri koroner (PAK) yang menyumbang angka kesakitan dan kematian yang tinggi di seluruh dunia. ${ }^{1,2}$ Selama ini data yang ada menunjukkan perbedaan angka kejadian PAK maupun infark miokardium akut antara perempuan premenopause dan laki-laki pada kelompok usia yang sama. ${ }^{3}$ Data tersebut mendukung dugaan pentingnya peranan hormon seks sebagai etiologi PAK dan juga berkaitan dengan sifat proteksi hormon seks perempuan bila dibanding dengan hormon seks laki-laki terhadap sistem kardiovaskular. Angka kejadian infark miokardium akut yang tinggi pada lakilaki usia lanjut juga menimbulkan dugaan pengaruh penurunan kadar testosteron sesuai usia pada proses terjadinya infark miokardium akut. ${ }^{4}$ Berbagai macam penelitian yang terutama dilakukan pada pasien laki-laki menunjukkan bahwa terdapat abnormalitas kadar hormon seks pada pasien infark miokardium serta terdapat hubungan antara kadar hormon seks dan derajat

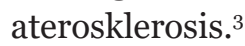

Selain perbedaan kejadian PAK dan infark miokardium akut, didapat pula perbedaan luaran pascainfark miokardium antara laki-laki dan perempuan berkaitan dengan perbedaan respons fisiologis yang diakibatkan oleh perubahan kadar hormon seks pascainfark miokardium akut. Penelitian yang telah dilaksanakan menunjukkan bahwa proses remodeling ventrikel kiri atau cardiac wound healing pascainfark miokardium akut dipengaruhi oleh hormon estrogen dan testosteron.

Dalam tubuh manusia testosteron dikenal dalam berbagai bentuk, sebagian besar terikat dengan albumin yang telah dikenal sebagai sex hormon binding globulin (SHBG) dan sebagian kecil berada dalam keadaan bebas tidak terikat dengan protein apapun yang dikenal sebagai testosteron yang bebas. Selain hal itu, dikenal pula testosteron bioavailabel yang merupakan testosferon gabungan antara testosteron bebas dan testosteron yang terikat dengan albumin. Di antara berbagai jenis testosteron tersebut, hanya testosteron bioavailabel yang dianggap memiliki fungsiutama dikarenakan testosteron bioavailabel memiliki kemampuan untuk berikatan dengan sel dalam jaringan dan menimbulkan efek fisiologis. ${ }^{5}$

Penilaian tentang perubahan struktur dan fungsi akibat proses remodeling ventrikel kiri pascainfark miokardium dapat dilakukan dengan berbagai cara, salah satunya dengan pemeriksaan ekokardiografi transtorakal dua dimensi yang bersifat noninvasif. ${ }^{6,7}$

Tujuan penelitian ini mengetahui perubahan kadar testosteron pada pasien infark miokardium akut serta pengaruh testosteron pada anatomi dan fungsinya ventrikel kiri sebagai parameter proses remodeling pascainfark miokardium akut berdasarkan pemeriksaan ekokardiografi.

\section{Metode}

Penelitian ini dilakukan menggunakan metode observasional analitik secara longitudinal selama periode bulan Maret 2015 sampai Oktober 2015. Pemilihan subjek penelitian dilakukan secara konsekutif terhadap pasien laki-laki yang datang ke RSUP Dr. Hasan Sadikin Bandung dengan diagnosis infark miokardium akut baik yang disertai dengan elevasi segmen ST maupun tanpa elevasi segmen ST. Dilakukan pengumpulan data sosiodemografik, faktor risiko PAK, dan juga laboratorium dasar.

Sampel darah pasien untuk pemeriksaan testosteron diambil dari vena antekubiti dan serum disimpan pada suhu $-80^{\circ} \mathrm{C}$ hingga sampel siap untuk dilakukan pemeriksaan. Pemeriksaan untuk kadar testosteron total mempergunakan kit biovendor testosterone ELISA (Biovendorlaboratorni medicina a.s.) dan testosteron bebas menggunakan kit biovendor human free testosterone ELISA (Biovendor-laboratorni medicina a.s.). Kadar testosteron bioavailabel dihitung mempergunakan rumus yang diajukan oleh Vermeulen dkk., Sodegard dkk., dan EmadiKonjin dkk. sebagai berikut:

$\operatorname{BAT}(\mathrm{mol} / \mathrm{L})=\{(\mathrm{kat} \times[$ albumin $] \times[\mathrm{FT}] /(1+$ kat $\times[\mathrm{FT}])\}-[\mathrm{FT}]$

BAT adalah testosteron bioavailabel, kat adalah konstanta asosiasi ikatan testosteron dengan albumin, dan FT adalah testosteron bebas.

Anatomi dan fungsi ventrikel kiri dinilai berdasarkan atas pemeriksaan mempergunakan ekokardiografi transtorakal dua dimensi memakai 
mesin ekokardiografi general electric vivid 7 (GE Health Medical) dengan transducer linear array M4S 1,5-3,6 mHz. Dilakukan juga penilaian ejection fraction (EF), fractional shortening (FS), dimensi sistol dan diastol ventrikel kiri (LVEDd dan LVEDs), LV mass, LV mass index, relative wall thickness (RWT), mitral inflow E/A, serta E/e' septal. Hasil pemeriksaan disimpan dalam format DICOM dan pengukuran secara off line dilakukan menggunakan sistem analisis gambar EchoPAC 11 (GE Health Medical).

Pemeriksaan kadar testosteron itu maupun pemeriksaan ekokardiografi dilakukan sebanyak dua kali, pemeriksaan pertama dilakukan dalam waktu 48 jam pertama sejak pasien datang ke rumah sakit dan pemeriksaan kedua dilakukan 4 sampai 6 minggu pascaperawatan. Data disajikan dalam bentuk rata-rata dan simpangan baku, median, serta proporsi. Dilakukan uji normalitas data menggunakan uji Kolmogorov Smirnov, dilanjutkan dengan analisis bivariat dengan uji korelasi Pearson bila data berdistribusi normal dan uji Spearman bila data berdistribusi tidak normal. Kemaknaan ditentukan berdasarkan nilai $\mathrm{p}<0,05$. Perhitungan statistik dikerjakan dengan bantuan piranti lunak IBM SPSS Statistics versi 22.o. Penelitian dilaksanakan setelah mendapat persetujuan dari KomiteEtikPenelitian Kesehatan Fakultas Kedokteran Universitas Padjadjaran, Bandung No. 671/UN6.C2.1.2/KEPK/PN/2014.

\section{Hasil}

Selama periode penelitian terdapat 79 pasien infark miokardium akut laki-laki, namun 19 pasien di antaranya dikeluarkan dari penelitian dengan alasan 4 pasien meninggal dunia dan 15 pasien tidak kembali untuk pemeriksaan ulangan sesuai prosedur penelitian. Sebanyak 60 pasien akhirnya diikutsertakan dalam penelitian ini.

Rentang usia subjek penelitian ini $40-70$ tahun dengan rata-rata $56,16 \pm 8,48$ tahun. Indeks massa tubuh rata-rata adalah $24,35 \pm 3,19 \mathrm{~kg} / \mathrm{m}^{2}$, nilai tersebut tergolong overweight berdasarkan atas kriteria Asia, namun masih tergolong normal berdasarkan kriteria WHO.

Tabel 1 Karakteristik Subjek Penelitian

\begin{tabular}{lc}
\hline \multicolumn{1}{c}{ Karakteristik } & $\mathbf{n = 6 0}$ \\
\hline Usia (tahun) & \\
Rata-rata \pm SB & $56,16 \pm 8,48$ \\
Median & 56,000 \\
Rentang (min.-maks.) & $40,00-77,00$ \\
Indeks massa tubuh (kg/m²) & \\
Rata-rata \pm SB & $24,35 \pm 3,19$ \\
Median & 24,32 \\
Rentang (min.-maks.) & $17,30-33,56$ \\
Diagnosis & \\
STEMI (n, \%) & $46(77)$ \\
NSTEMI (n, \%) & $14(23)$ \\
Onset nyeri (jam) & \\
Rata-rata \pm SB & $19,11 \pm 24,47$ \\
Median & 8,00 \\
Rentang (min.-maks.) & $1,00-96,00$ \\
Faktor risiko penyakit jantung koroner & \\
Dislipidemia (n, \%) & $47(78)$ \\
Merokok (n, \%) & $46(77)$ \\
Hipertensi (n, \%) & $40(67)$ \\
Diabetes melitus (n, \%) & $10(17)$ \\
Riwayat keluarga dengan PAK (n, \%) & $3(5)$ \\
1 faktor risiko (n, \%) & $5(8)$ \\
2 faktor risiko (n, \%) & $28(47)$ \\
$\geq 3$ faktor risiko (n, \%) & $27(45)$ \\
\hline
\end{tabular}


Sebanyak $77 \%$ orang pasien datang dengan diagnosis infark miokardium akut yang disertai elevasi segmen ST (STEMI) onset nyeri dengan rata-rata sejak pertama kali timbul angina hingga

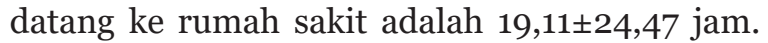
Sebagian besar pasien (92\%) memiliki minimal 2 faktor risiko PAK dengan faktor risiko terbanyak adalah dislipidemia, diikuti merokok, hipertensi, diabetes melitus, serta riwayat keluarga dengan PAK (Tabel 1).

Berdasarkan atas data laboratorium yang diperlihatkan pada Tabel 2 terdapat peningkatan kadar CKMB rata-rata yang merupakan hasil biomarka infark miokardium lebih dari dua kali di atas nilai normal. Terdapat pula peningkatan kadar troponin $\mathrm{T}$, sebagian besar berada pada rentang kadar 0,1-2 $\mu \mathrm{g} / \mathrm{L}$. Kadar leukosit rata-rata sebesar $11.907,79 \pm 3.728,73 / \mathrm{mm}^{3}$ menunjukkan peningkatan yang mengindikasikan telah terdapat proses inflamasi pascainfark miokardium. Hasil profil lipid menunjukkan kadar kolesterol total, LDL, dan kadar trigliserida serum rata-rata dalam batas normal, sedangkan kadar HDL rendah bila dibandingkan dengan kadar normal. Gambaran radiologis menunjukkan $80 \%$ pasien memiliki pembesaran ukuran jantung (kardiomegali).

Kadar testosteron total, testosteron bebas, dan testosteron bioavailabel diperiksa berulang dalam rentang waktu 4-6 minggu. Uji normalitas data mempergunakan uji Kolmogorov-Smirnov pada variabel testosteron total, testosteron bebas maupun testosteron bioavailabel memperlihatkan

Tabel 2 Data Dasar Laboratorium dan Radiologis

\begin{tabular}{|c|c|}
\hline Karakteristik & $n=60$ \\
\hline $\begin{array}{l}\text { CKMB (U/L) } \\
\text { Rata-rata } \pm \text { SB } \\
\text { Median } \\
\text { Rentang (min.-maks.) }\end{array}$ & $\begin{array}{c}87,71 \pm 91,27 \\
50,00 \\
17,00-373,00\end{array}$ \\
\hline $\begin{array}{l}\underset{<0,1}{\operatorname{Troponin}} \mathrm{T}(\mu \mathrm{g} / \mathrm{L}) \\
\quad 0,1-2 \\
\quad>2\end{array}$ & $\begin{array}{c}2(3) \\
41(69) \\
17(28)\end{array}$ \\
\hline $\begin{array}{l}\text { Leukosit (/mm } \\
\text { Rata-rata } \pm \text { SB } \\
\text { Median } \\
\text { Rentang (min.--maks.) }\end{array}$ & $\begin{array}{c}11.907,79 \pm 3.728,73 \\
11.400,00 \\
4.460,00-24.900,00\end{array}$ \\
\hline $\begin{array}{l}\text { Kolesterol total (mg/dL) } \\
\text { Rata-rata } \pm \text { SB } \\
\text { Median } \\
\text { Rentang (min.--maks.) }\end{array}$ & $\begin{array}{c}178,62 \pm 44,243 \\
174,00 \\
102,00-297,00\end{array}$ \\
\hline $\begin{array}{l}\text { LDL (mg/dL) } \\
\text { Rata-rata } \pm \text { SB } \\
\text { Median } \\
\text { Rentang (min.-maks.) }\end{array}$ & $\begin{array}{c}126,93 \pm 37,603 \\
121,00 \\
55,00-218,00\end{array}$ \\
\hline $\begin{array}{l}\text { HDL (mg/dL) } \\
\text { Rata-rata } \pm \text { SB } \\
\text { Median } \\
\text { Rentang (min.--maks.) }\end{array}$ & $\begin{array}{c}38,81 \pm 9,43 \\
37,00 \\
23,00-60,00\end{array}$ \\
\hline $\begin{array}{l}\text { Trigliserida (mg/dL) } \\
\text { Rata-rata } \pm \text { SB } \\
\text { Median } \\
\text { Rentang (min.--maks.) }\end{array}$ & $\begin{array}{c}134,96 \pm 55,44 \\
118,00 \\
54,00-366,00\end{array}$ \\
\hline $\begin{array}{l}\text { Rasio kardio-toraks (\%) } \\
\geq 50 \text { (kardiomegali) } \\
<50\end{array}$ & $\begin{array}{l}48(80 \%) \\
12(20 \%)\end{array}$ \\
\hline
\end{tabular}


bahwa data berdistribusi tidak normal. Dengan demikian, untuk dapat melihat perbedaan kadar testosteron rata-rata pada pemeriksaan pertama dan kedua digunakan uji Wilcoxon. Hasil analisis statistik yang diperoleh disajikan dalam Tabel 3 testosteron bebas maupun kadar testosteron bioavailabel yang tidak bermakna.

Analisis korelasi antara berbagai testosteron dan parameter ekokardiografi ditampilkan pada Tabel 4 .

Tabel 3 Perbandingan Kadar Testosteron

\begin{tabular}{lccc}
\hline \multicolumn{1}{c}{ Variabel } & Pemeriksaan I & Pemeriksaan II & p \\
\hline Testosteron total (ng/dL) & & & \\
$\quad$ Rata-rata \pm SB & $785,00 \pm 661,76$ & $822,33 \pm 365,64$ & $0,004^{*}$ \\
Median & 845,00 & 900,00 & \\
Rentang (min.-maks.) & $50,00-5 \cdot 060,00$ & $40,00-1.480,00$ & \\
Testosteron bebas (ng/dL) & & & \\
$\quad$ Rata-rata \pm SB & $24,66 \pm 17,91$ & $19,00 \pm 15,24$ & 0,067 \\
$\quad$ Median & 24,86 & 16,59 & \\
$\quad$ Rentang (min.-maks.) & $0,31-70,69$ & $0,46-60,60$ & \\
Testosteron bioavailabel (ng/dL) & & & \\
$\quad$ Rata-rata \pm SB & $475,21 \pm 353,10$ & $394,98 \pm 314,85$ & 0,166 \\
Median & 487,20 & 341,40 & \\
Rentang (min.-maks.) & $4,10-1.317,40$ & $9,30-1.059,00$ &
\end{tabular}

Keterangan: nilai $\mathrm{p}$ dihitung dengan uji Wilcoxon. Nilai kemaknaan berdasarkan $\mathrm{p}<\mathrm{0,05}$, sangat bermakna bila $\mathrm{p}<0,01$. Tanda * menunjukkan signifikan atau bermakna secara statistik

berikut ini.

Berdasarkan data yang diperlihatkan pada Tabel 3 tampak peningkatan kadar testosteron total yang bermakna serta penurunan kadar
Berdasarkan hasil uji Rank Spearman tampak bahwa testosteron total tidak memiliki korelasi yang bermakna dengan berbagai parameter ekokardiografi, sedangkan testosteron bebas dan

Tabel 4 Korelasi antara Testosteron dan Parameter Ekokardiografi

\begin{tabular}{lcccccc}
\hline \multirow{2}{*}{$\begin{array}{c}\text { Parameter } \\
\text { Ekokardiografi }\end{array}$} & \multicolumn{2}{c}{$\begin{array}{c}\text { Testosteron } \\
\text { Total }\end{array}$} & \multicolumn{2}{c}{$\begin{array}{c}\text { Testosteron } \\
\text { Bebas }\end{array}$} & \multicolumn{2}{c}{$\begin{array}{c}\text { Testosteron } \\
\text { Bioavailabel }\end{array}$} \\
\cline { 2 - 7 } & $\mathbf{r}$ & $\mathbf{p}$ & $\mathbf{r}$ & $\mathbf{p}$ & $\mathbf{r}$ & $\mathbf{p}$ \\
\hline LV end diastolic diameter (LVEDd) & $-0,054$ & 0,684 & 0,172 & 0,188 & 0,194 & 0,137 \\
& & & & & & \\
LV end systolic diameter (LVEDs) & $-0,058$ & 0,662 & 0,129 & 0,326 & 0,199 & 0,127 \\
& & & & & & \\
Ejection fraction (EF) & $-0,079$ & 0,549 & 0,087 & 0,508 & 0,000 & 0,998 \\
Fractional shortening (FS) & $-0,136$ & 0,302 & 0,024 & 0,854 & $-0,071$ & 0,589 \\
LV mass & 0,003 & 0,983 & $-0,148$ & 0,258 & $-0,122$ & 0,353 \\
LV mass index (LVMI) & $-0,002$ & 0,988 & $-0,167$ & 0,203 & $-0,142$ & 0,279 \\
Relative wall thickness (RWT) & 0,104 & 0,428 & $-0,302$ & $0,019^{*}$ & $-0,316$ & $0,014^{*}$ \\
Mitral E/A & $-0,079$ & 0,550 & $-0,094$ & 0,475 & $-0,148$ & 0,259 \\
E/e'septal & 0,110 & 0,401 & $-0,119$ & 0,364 & $-0,161$ & 0,219 \\
\hline
\end{tabular}

Keterangan: nilai $\mathrm{p}$ dihitung dengan uji korelasi Spearman. Nilai kemaknaan $\mathrm{p}<0,05$. Tanda *menunjukkan signifikan atau bermakna secara statistika. $r$ menunjukkan koefesien korelasi sesuai kriteria Guillford 
testosteron bioavailabel menunjukkan korelasi yang bermakna dengan parameter relative wall thickness (RWT) dengan nilai p berturut-turut o,019 dan 0,014.

\section{Pembahasan}

Pada penelitian ini telah dilakukan pemeriksaan kadar testosteron total, testosteron bebas, dan juga testosteron bioavailabel serum pada pasien infark mioardium akut laki-laki sebanyak dua kali dengan rentang waktu 4-6 minggu. Berdasarkan data pada Tabel 3 tampak peningkatan yang bermakna kadar testosteron total rata-rata dari $785,00 \pm 66,76 \mathrm{ng} / \mathrm{dL}$ menjadi 822,33 $\pm 365,64 \mathrm{ng} /$ $\mathrm{dL}(\mathrm{p}=0,004)$. Walaupun terdapat peningkatan kadar testosteron total, namun keduanya masih berada dalam rentang kadar yang normal, yaitu 240-950 ng/dL. Peningkatan kadar testosteron total pada penelitian ini sesuai dengan hasil penelitian yang dilakukan oleh Wickramatilake dkk. ${ }^{8}$ yang secara khusus telah mengevaluasi fluktuasi kadar testosteron total pada pasien pascasindrom koroner akut. Peningkatan kadar testosteron pada fase awal proses remodeling pascainfark miokardium tampaknya berkaitan dengan mekanisme tubuh dalam hal upaya untuk mempertahankanfungsiorganjantung. Penelitian oleh Golden dkk. ${ }^{9}$ pada kultur miosit ventrikel tikus yang diberikan testosteron menunjukkan peningkatan kemampuan kontraktilitas ventrikel yang ditandai dengan peningkatan 21\% peak shortening dan penurunan $18 \%$ time to peak shortening.

Penelitian ini memperlihatkan hasil penurunan kadar testosteron bebas maupun testosteron bioavailabel yang tidak bermakna. Walaupun kadar testosteron bebas dan juga testosteron bioavailabel mengalami penurunan, namun kadar kedua kolesterol pada pemeriksaan pertama menunjukkan nilai di atas kadar normal pada semua kelompok usia yang sesuai dengan usia subjekpenelitian. Keadaantersebutmenunjukkan bahwa peningkatan kadar testosteron bebas maupun testosteron bioavailabel disebabkan oleh kedua jenis testosteron tersebut dibutuhkan oleh jaringan jantung untuk dapat mempertahankan fungsi kontraksi organ jantung. Walaupun pada pemeriksaan ulangan kedua terjadi penurunan, namun kadar keduanya tetap di atas ambang normal, hal tersebut menunjukkan bahwa kedua jenis testosteron tersebut masih tetap dibutuhkan oleh jaringan jantung karena proses remodeling masih terus berlangsung.

Penilaian proses remodeling berdasarkan pemeriksaan ekokardiografi menjadi salah satu teknik evaluasi yang cukup banyak dipergunakan mengingat bahwa teknik pemeriksaan ini relatif mudah dan murah bila dibanding dengan jenis pemeriksaan lainnya. Walaupun belum terdapat kesepakatan mengenai parameter ekokardiografi standar yang harus digunakan untuk penilaian proses remodeling, akan tetapi secara umum dipergunakan parameter yang dapat menilai anatomi dan fungsi ventrikel kiri.

Berdasarkan hasil penelitian yang disajikan pada Tabel 4 dapat dilihat bahwa kadar kolesterol total tidak mempunyai korelasi dengan berbagai parameter ekokardiografi yang dipergunakan dalam penelitian ini. Sementara kadar kolesterol bebas memiliki korelasi yang bermakna dengan relative wall thickness yang ditunjukkan dengan nilai $\mathrm{p}=0,019$. Hasil serupa juga ditunjukkan oleh kadar testosteron bioavailabel yang juga memiliki korelasi yang bermakna dengan relative wall thickness (nilai $\mathrm{p}=0,014$ ). Hubungan kedua jenis testosteron tersebut dengan relative wall thickness memiliki koefesien korelasi dengan arah negatif yang menunjukkan bahwa kadar testosteron bebas atau testosteron bioavailabel yang tinggi mampu menurunkan relative wall thickness. Hal ini diperlukan agar lapisan dinding ventrikel tidak mengalami proses hipertrofi yang berlebihan akibat dari pengaruh testosteron yang dapat mengganggu fungsi ventrikel kiri. Hasil penelitian ini juga serupa dengan sebagian hasil penelitian yang dilakukan Tivesten $d k k .{ }^{10}$ yang membuktikan bahwa testosteron berpengaruh secara bermakna terhadap parameter relative wall thickness.

Hasil penelitian ini juga menunjukkan bahwa testosteron yang berkorelasi bermakna dengan parameter ekokardiografi hanyalah testosteron bebas dan testosteron bioavailabel. Hal tersebut mengindikasikan bahwasanya efek fisiologis yang timbul dan juga berpengaruh pada perubahan struktur jantung pascainfark miokardium hanya terjadi jikalau terdapat ikatan testosteron yang 
mempunyai afinitas terhadap jaringan dengan jaringan jantung itu sendiri. Di antara berbagai jenis testosteron, hanya testosteron bioavailabel termasuk di dalamnya testosteron bebas yang memiliki kemampuan untuk berikatan dengan jaringan. Keadaan tersebut menjelaskan mengapa hanya testosteron yang bebas dan bioavailabel yang menunjukkan korelasi bermakna dengan parameter ekokardiografi karena hanya kedua testosteron tersebut yang berikatan dengan selsel jantung.

Dari hasil penelitian ini menunjukkan bahwa meskipun pada awalnya kadar kedua jenis testosteron itu berada di atas nilai normal oleh karena dibutuhkan untuk proses awal remodeling, namun dengan berjalannya waktu kadar kedua jenis testosteron mengalami penurunan untuk mencegah komplikasi akibat proses hipertrofi yang maladaptif pada dinding jantung.

Sebagai simpulan penelitian ini, testosteron mempunyai peranan dalam proses remodeling ventrikel kiri pascainfark miokardium akut yang ditandai dengan peningkatan kadar testosteron total juga disertai penurunan kadar testosteron bebas dan testosteron bioavailabel yang tidak bermakna, serta korelasi testosteron bebas dan testosteron bioavailabel dengan relative wall thickness.

\section{Daftar Pustaka}

1. World Health Organization. Fact Sheet no. 310 . The top ten causes of death. November 2008.

2. Departemen Kesehatan. Direktorat Bina Farmasi Komunitas dan Klinik. Ditjen Bina Kefarmasian dan Alat Kesehatan. Pharmaceutical care untuk pasien penyakit Jantung Koroner: fokus sindrom koroner akut. Jakarta: Departemen Kesehatan RI; 2006.
3. Phillips GB. Is atherosclerotic cardiovascular disease an endocrinological disorder? The estrogen-androgen paradox. J Clin Endocrinol Metab. 2005;90:2708-11.

4. Platz EA. Low testosterone and risk of premature death in older men: analytical and preanalytical issues in measuring circulating testosterone. Clin Chem. 2008;54(7):1110-2.

5. Singh G. What's the diffrence between bioavailable testosterone, free testosterone, and sex hormone-linked testosterone? What does each type do? 2015 (diunduh 30 Januari 2016). Tersedia dari: https://www. quora.com/Whats-the-difference-betweenbioavailable-testosterone-free-testosteroneand-sex-hormone-linked-testosteroneWhat-does-each-type-do.

6. Baysan O, Bolu E, Uzun M, Kilicaslan F, Erinc $\mathrm{K}$, Pinar M, dkk. Left ventricular function in male patients with secondary hypogonadism. Echocardiography. 2007; 24(3):222-7.

7. Mirdamadi A, Garakyaraghi M, Pourmaghaddas A, Bahmani A, Mahmoudi $\mathrm{H}$, Gharipour M. Beneficial effects of testosterone therapy on functional capacity, cardiovascular parameters, and quality of life in patiens with congestive heart failure. Biomed Res Int Epub. 2014;2014:392432.

8. Wickramatilake CM, Mohideen MR, Pathirana C. Fluctuations of testosterone in acute coronary syndrome. Sri Lanka J Diabetes Endocrinol Metab. 2013;3:8-11.

9. Golden KL, Marsh JD, Jiang Y, Moulden J. Acute actions of testosterone on contractile function of isolated rat ventricular myocytes. Eur J Endocrinol. 2005;152(3):479-83.

10. Tivesten A, Vandenput L, Labrie F, Karlsson MK, Ljunggren O, Mellstrom D, dkk. Low serum testosterone and estradiol predict mortality in elderly men. J Clin Endocrinol Metab. 2009;94(7):2482-8. 